Animal Production and Environment Received on: 19/02/2020 Accepted on: 07/07/2020

\title{
Thermal stress alters the basal value of serum proteins in laying hens
}

\section{O estresse térmico altera o valor basal das proteínas séricas em galinhas poedeiras}

\author{
GRUNITZKY, Larissa ${ }^{1}$ \\ https://orcid.org/0000-0001-9124-9386
}

CENTENARO, João Rogério ${ }^{1}$

https://orcid.org/0000-0002-6884-3237

SILVA, Natasha Rocha da ${ }^{1}$

https://orcid.org/0000-0003-4873-9341

PAULO, Julia de Moraes ${ }^{1}$

https://orcid.org/0000-0002-5261-6902

\author{
SILVEIRA, Alisson Minozzo da ${ }^{1}$ \\ https://orcid.org/0000-0002-9853-0602 \\ LOPES, Graciela Völz \\ https://orcid.org/0000-0001-8707-9564 \\ FELIX, Gisele Aparecida ${ }^{3}$ \\ https://orcid.org/0000-0002-7739-586X \\ BRAZ, Paulo Henrique ${ }^{1 *}$ \\ https://orcid.org/0000-0002-5519-061X
}

${ }^{1}$ Instituto Federal Farroupilha, Campus - Frederico Westphalen, Frederico Westphalen, Rio Grande do Sul, Brazil.

${ }^{2}$ Universidade Federal de Pelotas, Departamento de Ciência e Tecnologia Agroindustrial, Pelotas, Pelotas, Brazil.

${ }^{3}$ Centro Universitário da Grande Dourados - Departamento de Ciências Agrárias e Exatas, Dourados, Mato Grosso do Sul, Brazil

*Endereço para correspondência: paulo.braz@iffarroupilha.edu.br

\begin{abstract}
This study aimed to evaluate the effect of thermal stress on the physiological and metabolic parameters in laying hens and the microbiological quality of eggs. The experiment was performed with 50 Rhode Island Red hens in the initial laying phase, under standard diet, lodged in $20 \mathrm{~m}^{2}$ stalls under controlled temperature, for 30 days. The laying hens were randomly divided into two groups: G1 - the control group, which contained 10 hens exposed to the temperature of $17^{\circ} \mathrm{C} ; \mathrm{G} 2$ - the treatment group, which contained 40 hens exposed to the temperature of $30^{\circ} \mathrm{C}$. The physiological parameters evaluated were: cloacal temperature, body surface temperature, heart rate, respiratory rate, and weight. Biochemical tests included total protein, albumin, globulin, and glucose. The group subjected to thermal stress showed lower body weight, increased heart rate, a slight increase in the respiratory rate, and increase in body surface temperature when compared with the control group $(P<0.05)$, although no significant differences were observed regarding cloacal temperature. As for the metabolic parameters, the treated group showed an increase in total proteins and globulins compared with the control group $(P<0.05)$, while albumin remained at basal levels. Additionally, hypoglycemia was observed in the treated group. Samples from egg shells and yolk were subjected to the analyses for the detection of Salmonella spp. These microorganisms were not detected amongst the egg samples.
\end{abstract}


Keywords: Poultry farming, protein alterations, thermal stress, Salmonella spp.

\section{RESUMO}

O objetivo deste estudo foi avaliar o efeito do estresse térmico nos parâmetros físiológicos e metabólicos de poedeiras, bem como na qualidade microbiológica dos ovos. O experimento foi realizado com 50 poedeiras da raça Rhode Island Red, em fase inicial de postura, recebendo dieta padronizada, alojadas em baias com aproximadamente $20 \mathrm{~m}^{2}$, com temperatura controlada, durante um período de 30 dias. As aves foram aleatoriamente divididas em dois grupos: G1 - grupo controle contendo 10 poedeiras expostas a uma temperatura de $17{ }^{\circ} \mathrm{C}$; e $\mathrm{G} 2$ - grupo tratamento contendo 40 poedeiras expostas a uma temperatura de $30{ }^{\circ} \mathrm{C}$. Os parâmetros fisiológicos avaliados foram: temperatura cloacal, temperatura corporal superficial, frequência cardíaca, frequência respiratória e peso. Foram realizados os exames bioquímicos de proteína total, albumina, globulina e glicose. No grupo mantido sob estresse térmico foi observado menor peso corporal, aumento na frequência cardíaca, leve aumento na frequência respiratória e aumento na temperatura corporal superficial quando comparado ao grupo controle $(P<$ 0.05), enquanto que para temperatura cloacal não houve diferença entre os grupos. Com relação às avaliações metabólicas, foi observado um aumento nas proteínas totais e globulinas das aves do grupo tratado quando comparado ao grupo controle $(P<0.05)$, enquanto que a albumina se manteve a níveis basais. Adicionalmente, observou-se hipoglicemia no grupo tratado. Amostras da casca e gema dos ovos foram submetidas à análise de Salmonella spp.. O patógeno não foi detectado em nenhuma das amostras analisadas.

Palavras-chave: avicultura, alterações proteicas, estresse térmico, Salmonella spp.

\section{INTRODUCTION}

Animal welfare has been considered one of the top priorities of animal production, especially for laying hens, which require special care regarding environmental conditions. The physiological and metabolic parameters of animals are altered under high environmental temperatures. Defense systems in the body generate compensatory responses during exposure to thermal stress, resulting in the depletion of body energy stocks or diversion of food energy to the maintenance of homeothermy (Attia et al., 2020). Thermal stress causes direct losses in zootechnical performance, resulting in lower egg production and particularly in lower egg quality (Attia et al., 2018; Liu et al., 2020).

The poultry production chain is one of the most important economic activities for Brazilian animal production (ANUALPEC, 2019). The significant development of the Brazilian poultry industry allowed a significant increase in egg production. During the production cycle, the high performance of laying hens and egg quality are essential characteristics for producers (Castro et al., 2019). Regarding egg quality, previous studies have found eggs and egg-processing environments to be contaminated with Salmonella spp. (Penha Filho et al., 2010). In Brazil, this microorganism is a significant cause of bacterial foodborne disease, and most of 
the cases are linked to the consumption of eggs and egg-containing products (Brazil, 2018).

This study was to evaluate the effect of thermal stress on the physiological and biochemical parameters of Rhode Island Red laying hens and on the microbiological quality of their eggs.

\section{MATERIAL AND METHODS}

\section{Poultry husbandry}

The study was developed in the experimental area of the Federal Institute Farroupilha (IFFAR), Frederico Westphalen, Rio Grande do Sul, Brazil. All procedures were conducted according to the international practices for animal use and care, approved by the Committee of Ethics on Animal Experimentation of the Federal Institute Farroupilha (CEUA-IFFAR) under the protocol number 6739240418 .

A total of 50 Rhode Island Red laying hens in the initial laying phase, with 20 weeks of age, were included in this study. The experimental hens, with an equal bodyweight, were housed in a closed room, consisting of three sections of a cage-free aviary with $20 \mathrm{~m}^{2}$ each. The hens were housed under the same management and hygienic conditions, with a 16-hour lighting schedule and relative air humidity maintained around $70 \%$. All hens were fed ad libitum with the same commercial feed, with approximately $125 \mathrm{~g} / \mathrm{Kg}$ of moisture, $160 \mathrm{~g} / \mathrm{Kg}$ of crude protein, $25 \mathrm{~g} / \mathrm{Kg}$ of ether extract, $70 \mathrm{~g} / \mathrm{Kg}$ of crude fiber, and $150 \mathrm{~g} / \mathrm{Kg}$ of ash content. The facilities were equipped with a stainless-steel nipple drinker. The experiment started on March 14, 2019, and lasted for 30 days.
The 50 laying hens were randomly assigned into two groups: G1 - control group, containing 10 hens exposed to a temperature of $17{ }^{\circ} \mathrm{C}$; and $\mathrm{G} 2$ - treated group, containing 40 hens, divided into two stalls exposed to a temperature of 30 ${ }^{\circ} \mathrm{C}$. The temperature of $17{ }^{\circ} \mathrm{C}$ was considered as a thermoneutral condition, corresponding to the average outdoor temperature of the state of Rio Grande do Sul when the experiment was performed. The temperature of $30^{\circ} \mathrm{C}$ was considered as heat stress, agreeing with the reported in the literature (Attia et al., 2018).

\section{Physiological parameters, blood sampling, and biochemical analysis}

Over the experimental period, the following physiological parameters were weekly evaluated: cloacal temperature $\left({ }^{\circ} \mathrm{C}\right)$, body surface temperature $\left({ }^{\circ} \mathrm{C}\right)$, heart rate (beats/min), respiratory rate (breaths/min), and weight (g). The analyses of heart and respiratory rates were performed by counting the heartbeats and the breaths for one minute. A digital thermometer was used to measure the cloacal temperature, and an infrared digital thermometer was used to measure the body surface temperature, which was measured in different parts of the body including the comb (CT), dorsum (DT), foot (FT), and under the wings (UWT). The body surface temperature was calculated according to Richards (1971), with adaptations, using the formula: $\mathrm{BST}=(0.06 \times \mathrm{CT})+(0.7 \mathrm{x}$ DT $)+(0.09 \times$ FT $)+(0.15 \times$ UWT $)$.

At the end of the experiment, blood samples were collected from all animals to determine the biochemical constituents. A total of $1 \mathrm{~mL}$ of blood was collected from the ulnar vein using needles $(13 \times 0.45 \mathrm{~mm})$ and $1 \mathrm{~mL}$ standard syringes. The blood was 
collected in a tube without anticoagulant and immediately centrifuged $(5,000 \mathrm{rpm}$ $\mathrm{x} 5$ minutes) to obtain the serum, stored at $-20{ }^{\circ} \mathrm{C}$ for further analysis. The serum levels of total protein $(\mathrm{g} / \mathrm{dL})$, albumin $(\mathrm{g} / \mathrm{dL})$, globulin $(\mathrm{g} / \mathrm{dL})$, and glucose $(\mathrm{mg} / \mathrm{dL})$ were evaluated in a semiautomated biochemical analyzer using commercial kits (Labtest Diagnostica ${ }^{\circledR}$, Lagoa Santa, Minas Gerais, Brazil).

\section{Microbiological analysis}

The eggs were subjected to microbiological analysis at the beginning and end of the experimental period to evaluate the presence of Salmonella spp. The analytical unit was composed of a pool of six eggs from each group, with yolk and eggshell being analyzed separately. The detection of Salmonella spp. was performed according to the American Public Health Association (APHA, 2001). Briefly, $25 \mathrm{~g}$ of each sample (eggshell and yolk) was homogenized with $225 \mathrm{~mL}$ of buffered peptone water and incubated at $37^{\circ} \mathrm{C}$ for 16-24 h. After that, $0.1 \mathrm{~mL}$ and $1.0 \mathrm{~mL}$ aliquots were transferred to tubes containing Rappaport Vassiliadis broth and Tetrathionate broth, respectively. The tubes with Rappaport Vassiliadis broth were incubated at $42{ }^{\circ} \mathrm{C}$ for 24 hours, and the tubes with Tetrathionate broth were incubated at $37^{\circ} \mathrm{C}$ for $24 \mathrm{~h}$. After incubation, the broth cultures were inoculated into Xylose Lysine Deoxycholate agar and Bismuth Sulfite agar. The plates were incubated at $37^{\circ} \mathrm{C}$ for $24-48 \mathrm{~h}$. Up to five presumptive colonies were selected from each plate and were streaked on Triple Sugar Iron agar and Lysine Decarboxylase agar, and then inoculated into urea broth.

\section{Statistical analysis}

The experimental results for both physiological and metabolic parameters, comparing the control and treated groups, were analyzed with ANOVA, using the statistical software R CORE TEAM, version 3.5.2.

\section{RESULTS}

The physiological parameters were evaluated in laying hens exposed to the temperature of $17^{\circ} \mathrm{C}$ and thermal stress at $30^{\circ} \mathrm{C}$ for 30 days. The group subjected to thermal stress showed lower body weight, increased heart rate, slightly increased respiratory rate, and increased body surface temperature when compared with the control group $(P<$ 0.05), although no significant differences were observed as for cloacal temperature (Table 1). It was observed that the hens had lower body weight when subjected to thermal stress, which was caused by decreased feed intake. The heart rate was 210.3 beats/min in the treated group, while in the control group, it was 197 beats/min. The respiratory rate was higher in the treated group, with 31.1 breaths/min and 29.4 breaths/min for the treated and control groups, respectively. The body surface temperature was slightly higher in the treated group, with an increase of $3.1^{\circ} \mathrm{C}$ compared with the control group (Table 1). As a result, behavioral changes were observed among the animals subjected to thermal stress, such as spread wings, open beak, and labored breathing.

As for the metabolic parameters, the treated group showed increased total proteins and globulins when compared with the control group $(P<0.05)$, while albumin remained at basal levels (Table 2). Additionally, hypoglycemia was observed in the treated group (glucose $=$ 
$164 \mathrm{mg} / \mathrm{dL}$ ). Probably, thermal stress promoted a decrease in feed intake, generating hypoglycemia in the treated group.

No changes in laying or egg quality were seen during the experimental period. In order to determine whether thermal stress could increase the contamination of Salmonella spp. in eggs, eggs samples from laying hens exposed to the temperature of $17{ }^{\circ} \mathrm{C}$ and to thermal stress at $30^{\circ} \mathrm{C}$ were analyzed. Among the analyzed egg samples, none of them presented contamination by Salmonella.

Table 1. Values of physiological parameters in laying hens exposed to the temperatures of $17^{\circ} \mathrm{C}$ and $30^{\circ} \mathrm{C}$.

\begin{tabular}{lll}
\hline $\begin{array}{l}\text { Physiological } \\
\text { parameter* }\end{array}$ & $\begin{array}{l}\text { Control group } \\
\left(\mathbf{1 7}{ }^{\circ} \mathbf{C}\right)\end{array}$ & $\begin{array}{l}\text { Treated group } \\
\left(\mathbf{3 0}{ }^{\circ} \mathbf{C}\right)\end{array}$ \\
\hline CLOT $\left({ }^{\circ} \mathrm{C}\right)$ & $41.1 \pm 0.5^{\mathrm{a}}$ & $41.4 \pm 0.3^{\mathrm{a}}$ \\
BST $\left({ }^{\circ} \mathrm{C}\right)$ & $33.6 \pm 1.8^{\mathrm{a}}$ & $36.7 \pm 1.2^{\mathrm{b}}$ \\
HR (beats/min) & $197 \pm 24^{\mathrm{a}}$ & $210.3 \pm 28^{\mathrm{b}}$ \\
RR (breaths/min) & $29.4 \pm 1.2^{\mathrm{a}}$ & $31.1 \pm 0.3^{\mathrm{b}}$ \\
Weight $(\mathrm{g})$ & $1,850 \pm 255^{\mathrm{a}}$ & $1,575 \pm 202^{\mathrm{b}}$ \\
* CLOT - Cloacal temperature; BST - Body surface temperature; HR - Heart rate; RR
\end{tabular}

CLOT - Cloacal temperature; BST - Body surface temperature; HR - Heart rate; RR Respiratory rate. Average values and standard deviations are shown. Values in the same row followed by different letters are statistically different $(P<0.05)$.

Table 2. Seric levels of total protein, albumin, globulin, and glucose in laying hens exposed to the temperatures of $17^{\circ} \mathrm{C}$ and $30^{\circ} \mathrm{C}$.

\begin{tabular}{|c|c|c|c|c|c|}
\hline \multirow{2}{*}{$\begin{array}{l}\text { Biochemical } \\
\text { Parameter }\end{array}$} & \multicolumn{2}{|c|}{$\begin{array}{l}\text { Control group } \\
\left(17^{\circ} \mathrm{C}\right)\end{array}$} & \multicolumn{2}{|c|}{$\begin{array}{l}\text { Treated group } \\
\left(30^{\circ} \mathrm{C}\right)\end{array}$} & \multirow{2}{*}{$\begin{array}{l}\text { W } \quad(T<=t) \\
\text { bi-caudal }\end{array}$} \\
\hline & Higher & Lower & Higher & Lower & \\
\hline Total Protein $(\mathrm{g} / \mathrm{dL})$ & 8.7 & 5 & 14.5 & 12.3 & 0.00001 \\
\hline Albumin (g/dL) & 6.6 & 0.8 & 5.9 & 0.8 & 0.77064 \\
\hline Globulin (g/dL) & 6.4 & 1.6 & 13.1 & 2.3 & 0.0009 \\
\hline Glucose (mg/dL) & 536 & 120 & 164 & 52 & 0.05 \\
\hline
\end{tabular}

\section{DISCUSSION}

Poultry birds are homeothermic animals and are able to keep their body temperature stable (Lovegrove, 2017). In this study, the cloacal and body surface temperatures were evaluated, and the results are shown in Table 1. Even under thermal stress conditions, the laying hens kept homeothermic and showed a cloacal temperature within the physiological standards of the species. In adult poultry, the physiological temperature varies from $41{ }^{\circ} \mathrm{C}$ to $42{ }^{\circ} \mathrm{C}$, and these animals 
less tolerate high environmental temperatures than by other species (Brown-Brandl et al., 1997).

In this study, the body surface temperature was higher in the group exposed to thermal stress, with an increase of $3.1{ }^{\circ} \mathrm{C}$ compared with the control group. The temperature range that animals can tolerate is known as the thermoneutral zone, which can oscillate from $18{ }^{\circ} \mathrm{C}$ to $20{ }^{\circ} \mathrm{C}$ for laying hens (Abreu \& Abreu, 2004). If the temperature of the environment rises above a certain point, thermoregulatory mechanisms are activated and include vasodilatation, an increase in evaporative losses by the skin surface and respiratory tract (Paulino et al., 2019). High body surface temperature is related to increased blood flow to the skin, especially to non-feathered areas, as a result of vasodilatation, as well as to the upper respiratory passageways, to transport heat from the viscera onto the peripheral tissue (Giloh et al., 2011).

In this experiment, an increase in the heart and respiratory rates was observed in the treated group compared with the control group (Table 1), probably as compensatory factors to thermal stress. The typical respiration rate of chickens is approximately 30 breaths per minute, and we registered values of 31.1 breaths per minute in the treated group. The respiratory rate increases dramatically during high temperatures, and panting plays an important role in dissipating heat excess. However, panting is defined by a respiration rate higher than 150 breaths per minute, which was not observed in this study. Evaporative heat loss is an efficient compensatory mechanism for thermal regulation to avoid hyperthermia, especially because birds do not have sweat glands (Habashy et al., 2017).
Lower body weight was perceptive in the hens exposed to thermal stress, which showed an average weight of 1,575 g. The animals from the control group showed a weight average of $1,850 \mathrm{~g}$. Decreased feed intake is one of the major responses of laying hens to keep homeothermic and minimize heat production (Attia et al., 2016). Consequently, low weight gain and poor productive performance in laying hens exposed to stress are frequently observed (Liu et al., 2020). The reduction in feed consumption leads to less protein biosynthesis and/or less fat deposition. In this study, a significant increase in total proteins was observed in the treated group compared with the control group $(P=0.00001)$ (Table 2). An increase in the total protein levels may occur due to dehydration or increased globulins, associated with diseases or chronic bacterial infections. In female birds, a considerable increase in total protein concentrations also occurs before oviposition, which may be attributed to estrogen induction in the ovary, raising globulin fractions (Lumeij, 1987). In this study, the increase in serum levels of total proteins may be explained by the thermal stress effect on the immune system, increasing globulin levels.

The two main types of plasma proteins are albumin and globulins, which comprise $\alpha$-globulin, $\beta$-globulin, and $\gamma$ globulin. These proteins act on the immune system as transporters (hormones, vitamins, minerals, and lipids) or maintaining the plasmatic osmotic pressure (Melo et al., 2009). In acute or chronic inflammatory conditions, a rise in total proteins caused by high concentrations of $\alpha, \beta$, or $\gamma$ globulins may occur. Similarly, hens that do not adapt to external stress factors may present increased globulin levels 
(Melo et al., 2009). In our study, the treated group showed an increase in globulin concentrations compared with the control group $(P=0.0009)$. Albumin remained at basal levels. Although the synthesis of albumin comes mostly from food, there was no significant difference in the albumin levels between groups, being justified by protein production in the liver (Lagana et al., 2007).

In the group exposed to the temperature of $30{ }^{\circ} \mathrm{C}$, the glucose levels in the serum were lower compared with the control group (Table 2). This phenomenon can be related to a decrease in feed intake and exhaustion of the liver glycogen stock (Attia et al., 2010). Birds use glucose as an energy source to keep their homeostasis, and low blood glucose concentration can lead to hypoglycemia. The glucose level has been suggested to be a sensitive parameter to indicate stress levels in poultry (Nijdam et al., 2005). Zhang et al., (2009) reported hypoglycemia in broilers during the first 45 minutes of transportation to slaughterhouse, demonstrating that stress could quickly decrease blood glucose levels.

Heat stress can impair the integrity of the gut barrier by damaging the intestinal epithelial cells, increasing intestinal permeability, and inducing intestinal inflammation (Abdelqader et al., 2017). Environmental stress is also related to alterations in the normal intestinal microbiota. Additionally, environmental stress has been shown to induce the colonization of poultry by enteric pathogens, including Salmonella spp. (Burkholder et al., 2008). Such colonization in poultry increases the risk of carcass contamination during processing and may increase the potential for Salmonella to translocate to the reproductive tract, where it can contaminate eggs in formation.

There are two pathways for eggs to become contaminated with Salmonella. Direct contamination occurs during the egg formation in the reproductive tract of hens, whereas indirect contamination occurs after an egg has been laid, and Salmonella bacteria contaminating the outside of the egg penetrates through the shell membrane (Whiley \& Ross, 2015). In our study, it was verified that all egg samples were negative to Salmonella spp. both in the control and treated groups. Our results suggest that thermal stress did not increase the number of birds carrying Salmonella, and therefore did not affect the direct contamination of eggs by Salmonella. These results corroborate those performed by Barbosa Filho et al., (2005), who verified the absence of Salmonella spp. contamination in eggs when the laying hens were exposed to environments with temperatures of $35^{\circ} \mathrm{C}$ and $26^{\circ} \mathrm{C}$.

\section{CONCLUSION}

For the physiological parameters, all evaluated parameters were altered by thermal stress, except the cloacal temperature. Hens had a lower body weight caused by decreased feed intake, which generated hypoglycemia. The increase in surface temperature, heart rate, and respiratory rate occurred as compensatory factors to thermal stress. Serum biochemical analysis of the hens revealed that high temperatures caused changes in the metabolism of total proteins by increasing the serum levels of globulins. 


\section{ACKNOWLEDGMENTS}

To Fundação de Amparo à Pesquisa do Estado do Rio Grande do Sul (FAPERGS) and Conselho Nacional de Desenvolvimento Científico $e$ Tecnológico - EM, for granting a Scientific Initiation scholarship, supported by Instituto Federal Farroupilha (Notice n ${ }^{\circ}$ 049/2018).

\section{REFERENCES}

ABDELQADER, A., ABUAJAMIEH, M., HAMMAD, H., AL-FATAFTAH, A. Effects of dietary butyrate supplementation on intestinal integrity of heat-stressed cockerels. J. Animal Physiology Animal Nutrition, 2017.

ABREU, P.G. de; ABREU, V.M.N. Conforto térmico para aves.

Concórdia: Embrapa Suínos e Aves, v. 365, p. 3, 2004.

ANUALPEC (2019). Anuário da

Pecuária Brasileira (20th ed. Vol. 1). São Paulo, São Paulo, Brasil: Instituto FNP.

APHA. American Public Health Association. Compendium of methods for the microbiological examination of foods. 4th ed. Washington, DC: APHA Press, 2001.

ATTIA, Y.A.; ABOU-SHEHEMA, B.M.; ABDELLAH, A.A.; ALY, O.M.; EL-NAGGAR, A. S. Effect of ascorbic acid and/or alpha-tocopherol fortification on semen quality, metabolic profile, antioxidants status, and DNA of roosters exposed to heat stress. The Journal of Animal \& Plant Sciences, v. 30, n. 2, p. 325-335, 2020.
ATTIA, Y.A.; AL-HARTHI M.A.; ELNAGGAR A.S. Productive, physiological and immunological responses of two broiler strains fed different dietary regimens and exposed to heat stress. Italian Journal of Animal Science, v.17, n.3, p.686-697, 2018 .

ATTIA, Y.A.; EL AE-HEA, ABEDALLA, A.A.; BERIKA, M.A.; AL-HARTHI, M.A.; KUCUK, O.; SAHIN, K.; ABOU-SHEHEMA, B.M. Laying performance, digestibility and plasma hormones in laying hens exposed to chronic heat stress as affected by betaine, vitamin $\mathrm{C}$, and/or vitamin E supplementation. Springer Plus, v. 5, n. 1, p. 1619, 2016.

ATTIA, Y.A.; HASSAN, R.A.; TAG EL-DIN, A.E.; ABOU-SHEHEMA, B.M. Effect of ascorbic acid or increasing metabolizable energy level with or without supplementation of some essential amino acids on productive and physiological traits of slow-growing chicks exposed to chronic heat stress. Journal of Animal Physiology and Animal Nutrition, v. 95, n. 6, p. 744-755, 2010.

BARBOSA FILHO, J.A.D.; SILVA, M.A.N.; SILVA, I.J.O.; COELHO, A.A.D. Egg Quality in Layers Housed in Different Production Systems and Submitted to Two Environmental Conditions. Brazilian Journal of Poultry Science, v. 8, p. 23-28, 2005.

BRAZIL. Surtos de Doenças Transmitidas por Alimentos no Brasil. 2018.

https://portalarquivos.saude.gov.br/imag es/pdf/2018/janeiro/17/Apresentacao- 
Surtos-DTA-2018.pdf (23 March 2020, date last accessed).

BROWN-BRANDL, T.M.; BECK, M.M; SCHULTE, D.D; PARKHURST, A.M; DESHAZER, J.A. Physiological responses of tom turkeys to temperature and humidity change with age. Journal of Thermal Biology, v. 22, p. 43-52, 1997.

BURKHOLDER, K.M., THOMPSON, K.L., EINSTEIN, M.E., APPLEGATE, T.J., PATTERSON, J.A. Influence of stressors on normal intestinal microbiota, intestinal morphology, and susceptibility to Salmonella enteritidis colonization in broilers. Poultry Science, v. 87, p. 1734-1741, 2008.

CASTRO, F.L.P.; KIM, H.Y.; HONG, Y.G.; KIM, W.K. The effect of total sulfur amino acid levels on growth performance, egg quality, and bone metabolism in laying hens subjected to high environmental temperature.

Poultry Science, v. 98, n. 10, p. 49824993, 2019.

GILOH, M.; SHINDER, D.; YAHAV, S. Skin surface temperature of broiler chickens is correlated to body core temperature and is indicative of their thermoregulatory status. Poultry

Science, v. 91, n. 1, p. 175-188, 2011.

HABASHY, W.S.; MILFORT, M.C.; ADOMAKO, K.; ATTIA, Y.A.; REKAYA, R.;AGGREY, S.E. Effect of heat stress on amino acid digestibility and transporters in meattype chickens. Poultry Science, v. 96, n. 7, p. 2312-2319, 2017.

LAGANA, C.; RIBEIRO, A.M.L.; GONZALEZ, F.H.D.; LACERDA,
L.A.; KRATZ, L.R.; BARBOSA, P.R. Níveis dietéticos de proteína e gordura e parâmetros bioquímicos hematológicos e empenamento em frangos de corte estressados pelo calor. Revista da Sociedade Brasileira de Zootecnia. v. 36, p. 1783-1790, 2007.

LIU, M.; LU, Y.; GAO, P.; XIE, X.; LI, D.; YU, D.; YU, M. Effect of curcumin on laying performance, egg quality, endocrine hormones, and immune activity in heat-stressed hens. Poultry Science, v. 99, n. 4, p. 2196-2202, 2020.

LOVEGROVE, G.A. A phenology of the evolution of endothermy in birds and mammals. Biological Reviews, v. 92, p. 1213-1240, 2017.

LUMEIJ, J.T. The diagnostic value of plasma proteins and non-protein nitrogen substances in birds.

Veterinary Quarterly, v. 9, n. 3, p. 262-268, 1987.

MELO, D.C.; OLIVEIRA, D.A.A.; MELO, M.M.; JÚNIOR, D.V.; TEIXEIRA, E.A.; GUIMARÃES, S.R. Proteic electrophoretic profile of chitralada tilapia nilotic (Oreochromis niloticus) exposed to hypoxia chronic stress. Arquivo Brasileiro de Medicina Veterinária e Zootecnia, v. 61, n. 5, p. 1183-1190, 2009

NIJDAM, E.; DELEZIE, E.; LAMBOOIJ, E.; NABUURS, M.J.A.; DECUYPERE, E.; STEGEMAN, J.A. Feed withdrawal of broilers before transport changes plasma hormone and metabolite concentrations. Poultry Science, v. 84, p. 1146-1152, 2005. 
PAULINO, M.T.F.; OLIVEIRA, E.M.; GRIESER, D.O.; TOLEDO, J.B.;

Criação de frangos de corte $\mathrm{e}$ acondicionamento térmico em suas instalações: Revisão. PUBVET, v. 13, n. 2, p. 1-14, 2019.

PENHA FILHO, R.A.C.; PAIVA, J.B.; SILVA, M.D.; ALMEIDA, A.M.; BERCHIERI JUNIOR, A. Controle de Salmonella Enteritidis e Salmonella Gallinarum em aves utilizando vacina candidata viva contendo linhagem mutante atenuada de Salmonella Gallinarum. Vaccine, v. 28, n. 16, p. 2853-2859, 2010.

RICHARDS, S.A. The significance of changes in the temperature of the skin and body core of the chicken in the regulation of heat loss. The Journal of Physiology, v. 216, p. 1-10, 1971.

WHILEY, H.; ROSS, K. Salmonella and eggs: from production to plate.

International Journal of Environmental Research and Public Health. v. 12, p. 2543-56, 2015.

ZHANG, L; YUE, H.Y.; ZHANG, H.J.; XU, L.; WU, S.J.; YAN, H.J.; GONG, Y.S.; QI, G.H. Transport stress in broilers: I. Blood metabolism, glycolytic potential, and meat quality. Poultry Science, v. 88, p. 2033-2041, 2009. 